\title{
Analysis of Students' Need for Augmented Reality As An Art Learning Medium in Primary School Teacher Education at Universitas Sebelas Maret
}

\author{
Jenny Indrastoeti $\mathrm{SP}^{1}$, Tribudiharto ${ }^{2}$
}

\begin{tabular}{l} 
ARTICLE INFO \\
\hline Article History: \\
Received 30.04.2018 \\
Received in revised form \\
05.06 .2018 \\
Accepted \\
Available online 01.07 .2018
\end{tabular}

INTRODUCTION

The higher education sector can take greatest advantage of the increased use of technology, especially the Internet, educational products. Instrumental aids are one of the effective ways of controlling human learning Skinner (1954) Researchers have discussed that learning should occur in a blended environment where traditional classroom practices are combined with technologi call earning solutions. D'Souzaetal (2013)

In the visual art learning required audio visual media in order to facilitate students to understand the material presented. Art learning requires high imagination to pour into an interesting work of art. So augmented reality media is very appropriate used in art learning because this media helps to develop the imagination through three-dimensional images

Augmented Reality, is a technology that combining two-dimensional virtual objects and three dimensional into a real three dimensional environment then projecting these virtual objects in real-time. Three dimensions are usually abbreviated 3D or called the space of objects which has length, width, and height. The term is usually used in the arts, animation, and computers mathematics. Virtual objects display information in the form of labels or virtual objects that can only be seen with camera phone or computer. System in Augmented Reality works by analyzing real-time object captured in camera. Azuma (1997) Augmented reality applications show good potential in giving students more active, effective and meaningful learning processes. Moreover, augmented reality attracts research attention for its ability to allow students to be immersed in realistic experiences. Solak, E., and Cakir, R. (2015).

One important aspect in art education is the appreciation of archipelago art. The appreciation of the archipelago artw ork is a combination of aspects of sight (observation) and taste done by students to achieve full aw areness about the local culture and creative potential of the surrounding environment. The sensitivity in appreciating the artwork of archipelago in art education course is very useful to appreciate the diversity of existing archipelago w ork and can foster creativity and innovative ideas. Syaifuddin (2012)

Art education have a purpose, so that students can appreciate the work of art archipelago that can be poured on the work of mosaic, montage and collage, so it takes an interesting learning process. Augmented reality as media is expected to provide solutions in enabling students to achieve these goals. Development of

\footnotetext{
${ }^{1}$ Corresponding e-mail: yenny_pgsd@yahoo.co.id,orcid.org/0000-0002-1093-1488

${ }^{2}$ tibudiharto_pgsd@staff.uns.ac.id

${ }_{1,2}$, Lecturer of Elementary teacher education in Sebelas Maret University
} 
student art appreciation should prioritize practical activities, not just lectures or working on questions. Practice activities continued with evaluate artwork through art criticism activities, so students are creative doing appreciation. Pedagogic art criticism directed so that students appreciate their own w ork and thew ork of others. Syaifuddin (2012)

A study conducted by Virginia Tech and University of Georgia on approximately 1,400 university instructors indicated that most of the instructors felt that classroom technologies had a positive influence on their teaching and students' learning. Respondents noted that technology has helped them deliver quality information, present more complicated examples to students, and enhance the engagement and attention of students in classroom activities (Brill and Gallow ay 2007)

One type of emerging technology that can be used in conjunction with mobile devices is augmented reality (AR), which has already been proven to help in areas such as reading comprehension and spatial aw areness (Billinghurst\&Duenser, 2012). The purpose of AR is to augment, or enhance our real-world environment by super imposing images, videos, information, or audio onto it (Bonsor, 2016). If a student with a mobile device wanted to access AR, they would scan a trigger image, which would then result in an AR response (Brown, 2015). AR educational programs are student-centered and related to student interests. It allows students to explore the world in an interactive way, so this research wants to use AR as media in art education class. By using augmented reality media is expected to increase student art appreciation. AR technology can be utilized through desktops, mobile devices, and smartphones. The technology is portable and adaptable to avariety of scenarios. AR can be used to enhance content and instruction within the traditional classroom,supplement instruction in the art education classroom especially to display mosaic, collage and montage works

Augmented reality that was given three widely recognized traits in 1997: it merges real and virtual data, it can be interacted with in real time, and it is used in a 3D environment. Continued AR advancements were made, as were developments in mobile technology, until the two could be combined and thus used anywhere, any time (Arth et al., 2015; Craig, 2013). The ability to make AR more mobile and affordable creates educational opportunities for differentiation, as well as giving students an opportunity to, "manipulate virtual objects or representations of real objects that would otherwise be impossible to hold as well as learn tasks and skills hold as well as learn tasks and skills.

Needs analysis will help institutions analyze the short-term and long term needs for their

learning initiatives, and in turn will be instrumental in developing their learning strategies. Needs analysis can also provide information about the technological and other support services needed for their learning initiatives. Through a comprehensiveneeds assessment process, an institution can establish its lea rning goals (Khan, 2005).

Mitchell (1993) describes needs assessment/analysis as "an examination of the existing need for training within an organization". It identifies performance areas or programs within an organization where training should be applied. A needs analysis identifies the problem or need and then proceeds to identify the aims, content, implementation, target population and outcome of an intervention (Cohen, Manionand Morrison, 2007).

Needs assessment is one of the main investigative tools used by institutions to the identification of actual needs, gaps, and hidden parts in the system and other activities. Needs analysis can help institutions to match the needs of their target with the learning courses of art

Kaufman (1985) contends, that needs assessment focuses on the identification and justification of gaps in results and the manner in which these gaps are prioritized for attention. Through existing gaps, researchers get information about the actual situation, so it can be used as a basic information to develop the content of augmented reality material when used as a medium of art learning.The results of the needs assessment will be an important part of the information used in decision-making about developing augmented reality as an art instructional media

The result of the research conducted by (Lenhart,2015) showed that In particular, mobile 
technologies have increasingly become more pervasive in the personal lives of teachers and students, and as such, many schools have been trying to implement mobile learning through Bring Your Own Device (BYOD) policies (Grant, Tamim, Sw eeney, \& Ferguson, 2015). With 75\% of teenagers 13 to 17 years old reporting that they have or have access to a smartphone, administrators are seeking to advance lear ning opportunities with mobile computing devices

Based on the description above, it was concluded that the needs analysis of the use interactive learning media based on augmented reality is very important. Lecturers need interactive learning media based on augmented reality as an innovative learning.

Situation of the Problem

There are some problems that exist at the primary teacher education in Indonesia. the first problem faced by students is, the process of learning art does not use media based on technology, so less interesting learning, students less motivated and less interactive learning

The second problem is, the students lack knowledge of interactive media based on technology, so that needed interactive media such as Augmented reality. The third problem is the result of art learning and the ability to appreciate the students' less artw ork formulation of learning media that needs to be developed on art learning.

Aim of the Study

The aim of the study is to describe (1) the use of art learning media in primary school teacher education that has been happening in the field and (2) the needs of lecturers and students to appropriate media in art learning to improve the quality of learning. The research findings are expected to provide a reference in developing innovative augmented reality-based media in primary school teacher education institutions

\section{METHODS}

This research is a research beginning which is included in the pre stage development in research and procedures development ( $\&$ D) by Borg \& Gall (2007. This study is limited to analysis that the learning process in the field, has not been implemented as it is hopeful, and describes the needs of students on augmented reality that is used as a medium of art learning. The research is descriptive research, using qualitative approach. The research was held in primary school teacher education institutions

\section{Material}

The source of the data in this study is students and lectures, event, and documents. Needs (need assessment) is sourced from initial observations in the field and a review of relevant literature with this study. Collection techniques data in this study using questionnaire instrument needs analysis for lecturers and students. Before the questionnaire is used on the respondents, the instrument first tested the validity and reliability using correlation and Cronbach's alpha.Result from the instrument try out obtained, 19 items only one item is invalid because the correlation coefficient of 0.163 is smaller than $\mathrm{r}$ table 0.396 with $5 \%$ significance level. For the other 18 items valid because the correlation coefficient greater than $\mathrm{r}$ table 0.396 . That means 18 items can be used to collect data on the sample. Instrument reliability test obtained coefficient of Cronbach's Alpha 0.926 it means the instrument is reliable.

To know the reality in the field related to the learning process so far implemented, the researchers conducted observations on two different agencies randomly selected. Through need assessment about augmented reality needs of students who used as media of visual art, researcher

make an application that used as media of learning mosaic art, collage and montage. Prototype augmented reality as a learning medium continued in the next period. So this article only reports the results of augmented reality needs analysis that is used as a medium of art learning.

Data Analyses

The data was analyzed using interactive analysis as stated by Miles and Huberman (2009):14), they are (1) data collection, is part and parcel of data analysis activities. (2) data reduction, includes the process of 
selecting, sorting, simplifying, and data categorization. Data reduction is intended to facilitate organizing data, data analysis needs, and conclusion drawing. Data conditions at this stage still in the form of raw data. The data reduction takes place continuously from the beginning until the final research report is realized. is the process of summarizing, selecting the essentials, focusing on the important things, removing the unnecessary. (3) Data presentation is a systematic exposure of data by showing the closeness of the data flow relationship, and at the same time describe the truth happens, making it easier for researchers to make the right conclusions. Presentation of data research is generally presented in narrative-shaped descriptions. (3) Conclusion withdrawal is done since the data collection stage, that is by way of record and interpret phenomena that show order, conditions over and over, and dominant patterns.

\section{FINDINGS}

A total of 150 students were selected through cluster random sampling of which 30 students were from A class and remaining 35 were B class and 35 were C class. Of the 100 students selected, all of them were studying in elementary teacher education program. The two classes sampled are classes that are learning art. From sample students selected, the result of need assessment about augmented reality needs that used as media of art learning, majority of them were interested in augmented reality if used as a medium of art learning. Of the 100 sample students selected, $80 \%$ students are less knowledge about augmented reality technology, $70 \%$ students stated that ongoing art lesson have not yet used technology and less interesting. All student samples required technology - based media innovation in art learning. In this case that will be developed in the next stage is augmented reality as media art learning.

In the following table: data of students in art learning needs was delineated.

\begin{tabular}{|c|c|c|c|}
\hline No & Aspect & Description & $\%$ Persentage \\
\hline \multirow[t]{4}{*}{1.} & $\begin{array}{l}\text { The process of art } \\
\text { learning }\end{array}$ & $\begin{array}{l}\text { Less use of technology-based } \\
\text { media }\end{array}$ & $100 \%$ \\
\hline & & - Less interesting learning & $75 \%$ \\
\hline & & - Less motivating lesson & $80 \%$ \\
\hline & & - Less interactive learning & $80 \%$ \\
\hline \multirow[t]{3}{*}{2.} & Students' knowledge of & - Less technical skills & $70 \%$ \\
\hline & technology-based media & - Less critical understanding & $80 \%$ \\
\hline & & - Lesscomunicativeability & $85 \%$ \\
\hline \multirow[t]{3}{*}{3.} & Students' & - Audio Visual media & $65 \%$ \\
\hline & technology-based media & - Internet- based media & $70 \%$ \\
\hline & & - Media-based android/ smartphone & $90 \%$ \\
\hline \multirow[t]{3}{*}{4.} & Knowledge of art & - cognitive & $70 \%$ \\
\hline & & - $\quad$ affective & $50 \%$ \\
\hline & & - psychomotor & $60 \%$ \\
\hline
\end{tabular}

From the data table above is described that the art learning process that lasted so far is still traditional, less use of technology-based media, less interesting learning, less motivated and less interactive students. Almost $85 \%$ of students said the learning process of art less interactive. Students' knowledge of technology-based media is also lacking in particular the skills of operating media devices, as well as the ability to understand content and media functions. The ability to communicate, produce and create media content is also lacking. Almost $80 \%$ of students lack the ability to operate technology-based media. From the questionnaire obtained that the students need innovative and technology-based learning media, the choice of most students on the need for media art learning that is based on android or smart phone.So in this study developed augmented reality as a medium that is applied through smartphones

From the results of observation on learning activities and through document analysis of cognitive abilities of students quite well, but for affective ability, especially the ability to appreciate the art is still lacking. Students' skill in producing artwork is also less. This is caused by because the lessons are less interactive and less supported by the use of interactive media. 
Art learning requires a lot of practice in making artwork such as mosaics, collages and montages. By incorporating augmented reality into the learning process, it is expected to provide students with learning experiences about abstract concepts that may be difficult to understand. Augmented used as a medium can be used as an alternative media in drawing or creating w orks of art that have abstract concept netw ork.Soby using augmented reality as a medium is expected art learning will be more alive because students are invited to interact with the media and make them interested.This is as stated in theresearch of YujiaHuang, HuiLi, \& Ricci Fong. 2015, the children could design, control and interact with the animated objects generated by the AR application.

Students also reported that learning in an AR environment is more stimulating and appealing than viewing a traditional slidepresentation (i.e.,Microsoft PowerPoint, Smart Notebook) because they preferred the audio, video, and feeling as if they were part of the 3D model that was transposed into a real physical space (Serio et al., 2013).

\section{RESULT, DISCUSSION, AND SUGGESTIONS}

Based on the findings in this study obtained through questionnaires and observations and interviews lecturers have used learning media such as books, pictures and real objects and the environment. For the use of interactive technology-based learning media such as augmented reality has never been used, so learning art is less interactive. Saputri (2018) said that the use of learning media that was not in accordance with the material and topics of learning made students less motivated. Wu and Chiang (2013) shows that applying 3D animations provided more enthusiasm for the learning activity, better performance in understanding the appearances and features of objects and improve the spatial visualization capabilities.

The knowledge of students and lecturers in using interactive technology-based media such as augmented reality is still lacking, so it has never been applied in class. As various technologies become more embedded in daily use, it is important to reflect on how current and emerging technologies can enhance education (Buffington \& Patton, 2016). Therefore, the requirement to enhance education with the latest technologies continues to increase to the point where it is becoming an essential part of good teaching.

Students need interactive media used in learning art to make learning more interactive and motivated students in achieving learning goals, effectively and efficiently. Previous studies list the benefits provided by AR use in educational environments. It is known that while use of AR draw s student interest and attention on lessons, it also increases their motivation. Besides these features, AR has advantages such as providing student centered learning and learning by doing. (Delello, 2014)

Based on the research, it can be concluded that (1) Technology-based learning media has not been implemented in art learning so lecturers need to use interactive media based on augmented reality (2) Students need technology-based media to improve the quality of art learning.

From the results of this study it is suggested that learning interactive media based augmented reality learning be developed to be used in fine arts learning. It is expected to motivate students in learning and improve the quality of learning.

\section{REFERENCES}

Antonioli,M., Blake,M., \& Sparks,K. (2018). AugmentedRealityApplicationsinEducationThe JournalofTechnologyStudies. April, https://scholar.lib.vt.ed u/ejournals/JOTS/v40/v40n2/pdf/antonioli.pdf

Arth, C., L., Grasset, R., Langlotz, T., Mulloni, A., Schmalstieg, D., \& Wagner, D. (2015). The history of augmented reality: Developments in mobile AR over the last 50 years (pp. 1-41, Rep.). Austria: Tug.

Azuma,R.T. (1997). A Survey of Augmented Reality, Teleoperator and Virtual Environments(3355-385), Hughes Research Laboratories, Dept Of Computer Science UNC, Los Angles, US, azumaisl.hrl.hac.com, http://www.cs.unc.edu/azuma.

Badrul, H. Khan. (2005). E-Learning quick checklist. Hershey, PA: Information Science Publishing. Retrieved from http://BooksToRead.com/checklist

Billinghurst, M. (2002). Augmented reality in education. New Horizons for Learning, Seattle. 
Bonsor,K.(2016).How augmentedreality w orks.Retrievedfromhttp://computer.howstuffw orks.com/augmente d-reality.htm

Brown, P. (2015), November 02). How to transform your classroom with augmented

Brill, J. M., and Galloway, C. (2007). "Perils and promises: University instructors' integration of technology in classroom-based practices." Br. J. Edu. Technol., 38(1), 95-105.

Cohen,L.,Manion,L.,\&Morrison,K.(2007). Research methods in education. 6th Edition.London: Routledge.

C.-F. $\mathrm{Wu}$ and M.-C. Chiang. (2013). "Effectiveness of applying $2 d$ static depictions and $3 d$ animations to orthographic views learning in graphical course," Comput. Educ.,63, 28-42

D'Souza, D., Singh, U., Sharma, D., \& Ranjan, P. (2013). Educational technology in teaching and learning: Prospects and challenges, Patna Women's College, Patna Univ., Patna, India.

Delello, J. A. (2014). Insights from pre-service teachers using science-based augmented reality. Journal of Computers in Education, 1(4), 295\{311. http://doi.org/10.1007/ s40692-014-0021-y

Gall, M.D., Gall, J.P. and Borg, W.R. (2007) Educational Research an Introduction. 8th Edition, Pearson.

Grant, M. M., Tamim, S., Sweeney, J. P., \& Ferguson, F. K. (2015, July 30). Teaching and learning with mobile computing devices: case study in K-12 classrooms. TechTrends, 59(4), 32-45.

Hamid Mohammad AZIMI. (2013). Assessment of E-Learning need among students of colleges of education. Turkish Online Journal of Distance Education-TOJDE October ISSN 1302-6488 14 (4).

Huang,Y., Li,H. \& Fong,R. (2015). Using Augmented Reality in early art education: a case study in Hong Kongkindergartenhttps://w ww.tandfonline.com/doi/full/10.1080/03004430.2015.1067888?scroll=top\& needAccess=truediaksestgl.

Kaufman, R A. (1994). A needs assessment Audit. Performance and Instruction, 33(2). http://www2.uwstout.edu/content/lib/thesis/2009/2009messnera.pdf

Lenhart, A. (2015). Teens, social media \& technology overview 2015. Retrieved from http://www .pewinternet.org/2015/04/09/teens-social-media-technology-2015/

Miles, M. B\& Huberman, M.(2009). Analisis data Kualitatif. Jakarta : UI-Press

Mitchell,G.(1993).The Trainer's Handbook,The AMA Guide to EffectiveTraining, 2ndEdit. Amacom,NY,423pp.

Perdana, Mukhlis Yuzti. Dkk. (2012). Aplikasi Augmented Reality Pembelajaran Or Per napasan Manusia Pada Smartphone Android, Jurnal Teknik Informatika, 1,

1-11, （http://journal.pcr.ac.id/wp- content/uploads/2012/09/Jurnal_mukhlis.pdf)

Saputri,D.Y. Rukayah, Indriayu,M (2018). Assessment of interactive multimedia based on game in elementary school: A challenge into learning in 21stCentury. International Journal of Educational Research Review (IJERE), 3 (3), 1-8.

Syaifuddin. (2012). Montage mosaic learning collage for elementary school students. Surakarta

Serio,A. D., Ibanez, M. B., \& Carlos, D. K. (2013). Impact of an augmented reality system on students'motivation for a visual art course. Computers \& Education, 68, 586-596. http://dx.doi. org/10.1016/j.compedu.2012.03.002

Skinner, B. F. (1954). The science of learning and the art of teaching. Harv. Educ. Rev., 24, 86-97. 
Solak, E., \& Cakir, R. (2015). Exploring the effect of materials designed with augmented reality on language learners' vocabulary learning. Journal of Educators Online, 12(2).

Y.-H. Hung, C.-H. Chen, S.-W. Huang. (2017) Applying augmented reality to enhance learning: a study of different teaching materials. Journal of Computer Assisted Learning 33:3, pages 252-266. 